\title{
INFECTION STATUS AND MOLECULAR IDENTIFICATION OF DIGENEAN CERCARIAE IN SNAILS IN KIM SON DISTRICT, NINH BINH PROVINCE AND BA VI DISTRICT, HA NOI
}

\author{
Pham Ngoc Doanh", Hoang Van Hien, Bui Thi Dung, Ho Thi Loan \\ Institute of Ecology and Biological Resources, VAST, Vietnam
}

Received 25 June 2019, accepted 16 July 2019

\begin{abstract}
In this study, the molecular method was used to identify digenean cercariae from freshwater snails in Kim Son District (Ninh Binh Province) and Ba Vi District (Ha Noi). A total of 9 snail species were collected and examined for cercarial infection. Three snail species (Radix swinhoei, Angulyagra polyzonata, and Pomacea canaliculata) were not infected, while the other 6 species (Austropeplea viridis, Gyraulus convexiusculus, Parafossarulus striatulus, Bithynia fuchsiana, Melanoides tuberculata, and Tarebia granifera) were infected with digenean cercariae at low infection rates, ranging from $2.3 \%$ to $6.3 \%$. Seven cercarial groups were identified: Echinostome, Monostome, Parapleurophocercaria, Xiphidiocercaria, Fucocercaria, Gymnocephalous, and Megalurous. Snails $M$. tuberculata and $P$. striatulus were infected with 4 cercarial groups, $A$. viridis and $G$. convexiusculus snails were infected with 2 groups, 2 snail species $B$. fuchsiana and T. granifera were infected with one group of cercaria. The analyses of ITS2 sequences of the cercarial groups identified the larvae of 9 trematode species, namely Echinostoma revolutum, Echinochasmus japonicus, Notocotylus intestinalis, Philophthalmus gralli, Haplorchis pumilio, Procerovum cheni, Fasciola gigantica, Australapatemon burti, and Cyathocotyle prussica. Among them, the last three species, $P$. cheni, A. burti and C. prussica, were found for the first time in Vietnam. In addition, the ITS-2 sequence of Gymnocephalous cercariae which was previously identified as Sphaeridiotrema monorchis, from $P$. striatulus snail was $97 \%$ similar to that of Sphaeridiotrema pseudoglobulus. Likewise, ITS-2 sequence of Echinostome cercaria from B. fuchsiana snail was $93 \%$ similar to that of E. japonicus and that of Xiphidiocercaria cercaria from $M$. tuberculata snail was $93 \%$ similar to Lecithodendrium spathulatum.
\end{abstract}

Keywords: Digenean cercaria, freshwater snail, intermediate hosts.

Citation: Pham Ngoc Doanh, Hoang Van Hien, Bui Thi Dung, Ho Thi Loan, 2019. Infection status and molecular identification of digenean cercariae in snails in Kim Son district, Ninh Binh Province and Ba Vi district, Ha Noi. Academia Journal of Biology, 41(3): 31-38. https://doi.org/10.15625/2615-9023/v41n3.13893.

*Corresponding author email: pndoanh@yahoo.com

(O2019 Vietnam Academy of Science and Technology (VAST) 


\section{INTRODUCTION}

Parasitic trematodes have complex life cycles, requiring at least two hosts. Of which, the obligatory first intermediate hosts are mollusks (usually freshwater snails), where the development of larval stages (sporocyst, redia, and cercaria) takes place. Therefore, the identification of trematode larvae in snails helps to understand life cycles of trematodes and assess the trematode infection situation of humans and animals, providing a scientific basis for controlling the intermediate hosts of trematode transmission.

Cercarial larvae of trematode are classified into 38 groups (Schell, 1970). The determination of cercarial groups is based on morphological characteristics, although it is not easy to distinguish cercariae among various species. To overcome this limitation, molecular techniques have been used for the accurate identification of trematode cercariae (Chuboon and Wongsawad, 2009; Chontananarth and Wongsawad, 2010; Anucherngchai et al., 2016).

In Vietnam, surveys on trematode larvae in snails have been carried out in some locations. However, the previous reports mainly published the prevalence of trematode cercariae or morphological identification of cercarial groups (Le et al., 1990, 1995, 2000; The, 1993; Chau et al., 1996; Kim and Vinh, 1997; Dung et al., 2010; Hung et al., 2015; Clausen et al., 2015; Dung et al., 2019). In this study, we used a molecular technique to identify trematode larvae in freshwater snails in Kim Son District, Ninh Binh Province and Ba Vi District, Hanoi, where livestock and poultry are commonly raised.

\section{MATERIALS AND METHODS}

\section{Study sites}

Kim Son District, Ninh Binh Province and Ba Vi District, Ha Noi.

\section{Methods}

Freshwater snails were collected in Kim Son District, Ninh Binh Province and $\mathrm{Ba} \mathrm{Vi}$ District, Hanoi, and were classified according to Thanh et al. (1980).
The snails were examined for cercarial infection using the shedding and crushing methods. Each snail was kept separately in a shedding tube of $2 \times 2 \mathrm{~cm}$ (diameter $\times$ depth). In the next morning, the shedding tubes were observed under a stereoscopic microscope to detect cercariae escaped from the snails. The cercariae were transferred to a glass slide and covered with a cover glass for morphological observation under a microscope. The cercariae were classified into a group level according to the keys described by Schell, 1970, Frandsen and Christensen, 1984. Some cercariae were used for molecular analyses.

Then, the snails were examined to observe young larvae remaining in the snails using the crushing method. For small and soft snail species, the snails were pressed between 2 glass plates. For larger species of snails, a shear was used to remove the hard shell of the back of the screw and immerse it in a small water drop on the slide glass. The slide was checked under a microscope.

Cercarial samples were molecularly analyzed to identify species using ITS2 sequences, according to the following procedure: Genomic DNA from cercariae was extracted using the QIAamp DNA Mini Kit; the ITS2 sequence was amplified by PCR technique using a primer pair: 3S (forward primer, 5'-CGC TGG ATC ACT CGG CTC GT-3') and A28 (reverse primer, 5'-CCT GGT TAG TTT CTC TTC CGC- 3') (Bowles et al. 1993); the PCR products were purified using Qiaquick PCR purification Kit (Qiagen Inc., Tokyo, Japan). The forward and reverse strands were sequenced directly using the Genetic Analyzer 3130 using Big-Dye terminator cycle-sequencing kit v3.1 (Applied Biosystems). The obtained sequences were compared with DNA sequences available from GenBank with the BLAST search program.

\section{RESULTS}

\section{Cercarial infection in snails}

We collected 9 common snail species: Austropeplea viridis (syn. Lymnaea viridis), Radix swinhoei (syn. Lymnaea swinhoei), Parafossarulus striatulus, Bithynia fuchsiana, 
Melanoides tuberculata, Tarebia granifera, Gyraulus convexiusculus, Angulyagra polyzonata, and Pomacea canaliculata. The total of 1,910 snails from Ba Vi District and 2,340 snails from Kim Son District were examined. Trematode cercariae were found from 6 snail species with the prevalence ranging from $2.3 \%$ to $6.3 \%$, but not from 3 snail species, $R$. swinhoei, A. polyzonata and $P$. canaliculata (table 1).

Table 1. The prevalence of cercaria infection in freshwater snails

\begin{tabular}{|c|l|c|c|c|c|}
\hline \multirow{2}{*}{ No } & \multirow{2}{*}{ Snail species } & \multicolumn{2}{|c|}{ Kim Son, Ninh Binh } & \multicolumn{2}{c|}{ Ba Vi, Ha Noi } \\
\cline { 3 - 6 } & & No. examined & No. infected (\%) & No. examined & No. infected (\%) \\
\hline 1 & A. viridis & 200 & $5(2.5)$ & 350 & $9(2.6)$ \\
\hline 2 & R. swinhoei & 0 & & 100 & 0 \\
\hline 3 & G. convexiusculus & 220 & $5(2.3)$ & 260 & $9(3.5)$ \\
\hline 4 & T. granifera & 0 & & 240 & $8(3.3)$ \\
\hline 5 & M. tuberculata & 250 & $15(6.0)$ & 200 & $12(6.0)$ \\
\hline 6 & P. striatulus & 900 & $48(5.3)$ & 240 & $15(6.3)$ \\
\hline 7 & B. fuchsiana & 350 & $10(2.8)$ & 120 & $6(5.0)$ \\
\hline 8 & A. polyzonata & 220 & 0 & 200 & 0 \\
\hline 9 & P. canaliculata & 200 & 0 & 200 & 0 \\
\hline
\end{tabular}

\section{Identification of cercariae}

Table 2. The result of molecular identification of cercarial groups from snails

\begin{tabular}{|c|c|c|c|c|c|}
\hline \multirow[b]{2}{*}{ Snail species } & \multirow[b]{2}{*}{ Cercarial groups } & \multirow[b]{2}{*}{ Location } & \multicolumn{3}{|c|}{ Molecular identification based on ITS2 sequence } \\
\hline & & & Trematode species & $\begin{array}{c}\text { Similarity } \\
(\%)\end{array}$ & $\begin{array}{l}\text { Reference } \\
\text { sequence in } \\
\text { GenBank }\end{array}$ \\
\hline \multirow{5}{*}{ M. tuberculata } & Parapleurophocercaria 1 & $\begin{array}{l}\text { Ha Noi, } \\
\text { Ninh Binh }\end{array}$ & Haplorchis pumilio & 100.0 & KX815125 \\
\hline & Parapleurophocercaria 2 & Ninh Binh & Procerovum cheni & 100.0 & HM004164 \\
\hline & Monostome & $\begin{array}{l}\text { Ha Noi, } \\
\text { Ninh Binh }\end{array}$ & $\begin{array}{l}\text { Notocotylus } \\
\text { intestinalis }\end{array}$ & 100.0 & MH750029 \\
\hline & Xiphidiocercaria & $\begin{array}{l}\text { Ha Noi, } \\
\text { Ninh Binh }\end{array}$ & $\begin{array}{l}\text { Lecithodendrium } \\
\text { spathulatum }\end{array}$ & 93.0 & JF784192 \\
\hline & Megalurous & $\begin{array}{l}\text { Ha Noi, } \\
\text { Ninh Binh }\end{array}$ & $\begin{array}{l}\text { Philophthalmus } \\
\text { gralli }\end{array}$ & 100.0 & JX121231 \\
\hline \multirow{4}{*}{ P. striatulus } & Echinostome & $\begin{array}{l}\text { Ha Noi, } \\
\text { Ninh Binh }\end{array}$ & $\begin{array}{l}\text { Echinochasmus } \\
\text { japonicus }\end{array}$ & 99.1 & KT873314 \\
\hline & Gymnocephalous & $\begin{array}{l}\text { Ha Noi, } \\
\text { Ninh Binh }\end{array}$ & $\begin{array}{l}\text { Sphaeridiotrema } \\
\text { pseudoglobulus }\end{array}$ & 97.0 & GQ890330 \\
\hline & Monostome & $\begin{array}{l}\text { Ha Noi, } \\
\text { Ninh Binh }\end{array}$ & $\begin{array}{l}\text { Notocotylus } \\
\text { intestinalis }\end{array}$ & 100.0 & MH750029 \\
\hline & Fucocercaria & $\begin{array}{l}\text { Ha Noi, } \\
\text { Ninh Binh }\end{array}$ & $\begin{array}{l}\text { Cyathocotyle } \\
\text { prussica }\end{array}$ & 99.0 & MH521249 \\
\hline \multirow[t]{2}{*}{ A. viridis } & Echinostome & $\begin{array}{l}\text { Ha Noi, } \\
\text { Ninh Binh }\end{array}$ & $\begin{array}{l}\text { Echinostoma } \\
\text { revolutum }\end{array}$ & 100.0 & KF894682 \\
\hline & Gymnocephalous & Ha Noi & Fasciola gigantica & 99.9 & KX198631 \\
\hline \multirow{2}{*}{$\begin{array}{l}\text { G. } \\
\text { convexiusculus }\end{array}$} & Echinostome & Ha Noi & $\begin{array}{l}\text { Echinostoma } \\
\text { revolutum }\end{array}$ & 100.0 & KF894682 \\
\hline & Fucocercaria & Ha Noi & $\begin{array}{l}\text { Australapatemon } \\
\text { burti }\end{array}$ & 99.4 & JX977785 \\
\hline T. granifera & Parapleurophocercaria 1 & Ha Noi & Haplorchis pumilio & 100.0 & KX815125 \\
\hline B. fuchsiana & Echinostome & $\begin{array}{l}\text { Ha Noi, } \\
\text { Ninh Binh }\end{array}$ & $\begin{array}{l}\text { Echinochasmus } \\
\text { japonicus }\end{array}$ & 93.0 & KT873314 \\
\hline
\end{tabular}




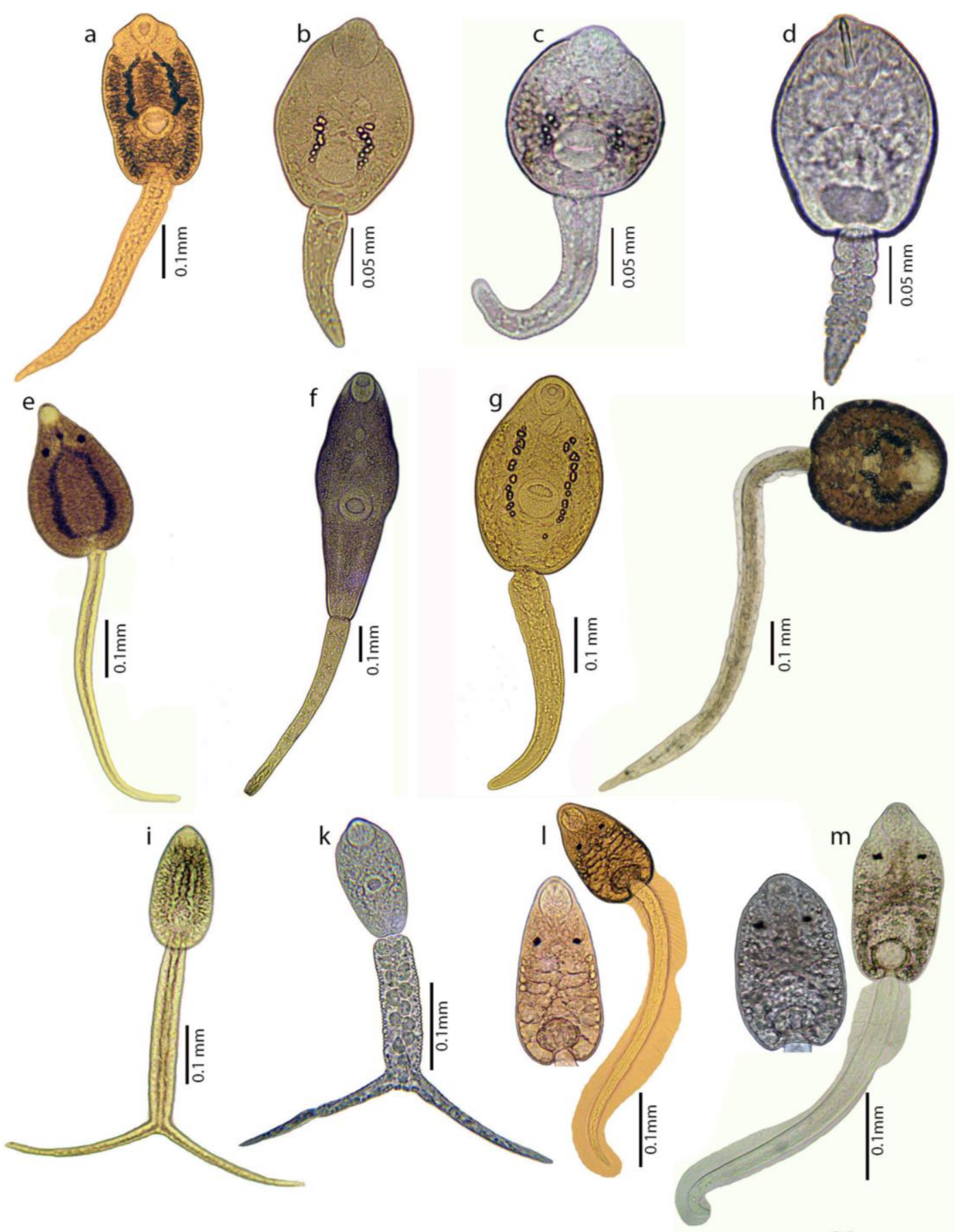

Figure 1. Cercarial groups of trematodes collected from snails

Note: a. Echinostome from snail G. convexiusculus; b. Echinostome from snail P. striatulus; c. Echinostome from snail B. fuchsiana; d. Xiphidiocercaria from snail M. tuberculata; e. Monostome from snail M. tuberculata; f. Megalurous from snail M. tuberculata; g. Gymnocephalous from snail $P$. striatulus; h. Gymnocephalous from snail A. viridis; i. Fucocercaria from snail P. striatulus; k. Fucocercaria from snail G. convexiusculus; 1. Parapleurophocercaria 1 from snail M. tuberculata; $\mathrm{m}$. Parapleurophocercaria 2 from snail M. tuberculata. 
Based on morphological characteristics, we identified 7 cercarial groups (fig. 1; Echinostome,

Monostome, Parapleurophocercaria, Xiphidiocercaria, Fucocercaria, Gymnocephalus and Megalurous). While snails $M$. tuberculata and $P$. striatulus were infected with 4 cercarial groups, snails $A$. viridis and $G$. convexiusculus were infected with two groups, and snails $B$. fuchsiana and T. granifera were infected with one cercarial group.

All cercarial groups were molecularly analyzed using ITS2 sequences as a marker. The results of the BLAST search identified the larvae of 9 trematode species with the similarities over $99 \%$ to the sequences deposited in GenBank. They are Echinostoma revolutum (100\%), Notocotylus intestinalis (100\%), Philophthalmus gralli (100\%), Haplorchis pumilio (100\%), Procerovum cheni (100\%), Fasciola gigantica (99.9\%), Australapatemon burti (99.4\%), Cyathocotyle prussica (99.0\%) and Echinochasmus japonicus (99.1\%). In addition, Gymnocephalus group from $P$. striatulus snails was 97\% similar to Sphaeridiotrema pseudoglobulus; Echinostome group from this snail species was $93 \%$ similar to E. japonicus, and Xiphidiocercaria group from $M$. tuberculata snail was $93 \%$ similar to Lecithodendrium spathulatum. The snail hosts, cercarial groups, trematode species identified by molecular analyses are shown in table 2.

\section{DISCUSSION}

According to previous reports, the prevalence of trematode larvae in freshwater snail species was relatively high. The (1993) reported the prevalence of $C$. sinenis cercariae in $M$. tuberculata in Nam Dinh Province up to $90 \%$. Le et al. (1995) found trematode larvae in $30.6 \%$ of $L$. swinhoei and $26.3 \%$ of $L$. viridis snails in Ha Tay Province. The survey conducted by Kim and Vinh (1997) showed the prevalence of Fasciola cercariae in $62.1 \%$ of Lymnaea snails in Bac Ninh Province. In contrast, recent surveys have revealed low prevalences of trematode larvae in freshwater snails. Dung et al. (2010) reported that $13.3 \%$ of M. tuberculata snails in Nghia Hung District, Nam Dinh Province was infected with trematode cercariae. A survey in Thai Binh, Nam Dinh, Ninh Binh, and Thanh Hoa Provinces revealed that the prevalence of trematode larvae in 13 snail species collected was generally low (Clausen et al. 2015). Hung et al. (2015) collected 7 snail species in Gia Vien District, Ninh Binh Province, and found a very low prevalence of cercariae in two snail species, M. tuberculata $(7 / 858=0.8 \%)$ and $B$. fuchsiana $(2 / 1,894=0.1 \%)$. Phuong et al. (2019) reported that the prevalence of cercarial infection in $M$. tuberculata snail was $14.3 \%$ in Ha Trung District, Thanh Hoa Province. Dung et al. (2019) surveyed in some suburban districts of Ha Noi, and found that among 9 snail species collected, 5 snails $(M$. tuberculata, $B$. fuchsiana, $A$. viridis, $G$. convexiusculus, Stenothyra messageri) were infected with cercarial larvae at low infection rates ranging from 0.3 to $2.6 \%$. The results of the present study also indicated that the infection rates of trematode larvae in freshwater snails were relatively low $(2.3 \%$ $6.3 \%$ ). These reflect a significant reduction of trematode infection in humans and animals in comparison to those in the past.

Previously published studies focused only on infection status of snails or identification of the cercarial groups. Le et al. (1995) described 3 cercarial groups (Echinostome, Fucorcercaria, and Xiphidiocercaria) from $L$. swinhoei and $L$. viridis snails in $\mathrm{Ha}$ Tay Province. Dung et al. (2010) identified 7 cercarial groups (Parapleurophocercous, Pleurophocercous, Echinostome, Xiphidiocercaria, Furcocercaria, Monostome, and Gymnocephalous) from snails in Nghia Hung, Nam Dinh Province. Clausen et al. (2012) mainly found Parapleurophocercous and Echinostome groups in Thai Binh, Nam Dinh, Ninh Binh, and Thanh Hoa Provinces. The survey by Hung et al. (2015) in Gia Vien District, Ninh Binh Province, showed that $B$. fuchsiana snails were infected with an Echinostome group, while $M$. tuberculata snails were infected with 4 groups: Echinostome, Xiphidiocercaria, 
Parapleurophocercous, and Fucorcercaria. Phuong et al. (2019) illustrated 5 cercarial groups, namely Amphistome, Echinostome, Megaluralous, Monostome, and Parapleurophocercous cercariae, in $M$. tuberculata snails in Ha Trung District, Thanh Hoa Province. Similarly, Dung et al. (2019) detected 6 cercarial groups; Parapleurophocercaria, Echinostome, Xiphidiocercaria, Monostome, Gymnocephalous, and Fucorcercaria from snails in some suburban districts of Ha Noi. Besprozvannykh et al. (2013) identified trematode larvae in 3 snail species, $B$. fuchsiana, P. striatulus, and M. tuberculata, collected in Nam Dinh Province. They obtained the larvae of 12 trematode species belonging to 8 families, Cyathocotylidae, Pleurogenidae, Paramphistomidae, Notocotylidae, Lecithodendriidae, Heterophyidae, Echinostomatidae. A species (E. japonicus, $N$. intestinalis and $S$. monorchis) were identified to the species level using experimental infection and molecular analysis based on the 28S rDNA sequence.

In the present study, using ITS2 sequence analysis, we accurately identified the larvae of nine trematode species (E. revolutum, $E$. japonicus, $N$. intestinalis, $P$. gralli, $H$. pumilio, , F. gigantica, A. burti, C. prussica, and $P$. cheni). Among them, three species, $A$. burti, $C$. prussica, and $P$. cheni, were first detected in Vietnam. It should be noted that M. tuberculata snail has been reported as the first intermediate host of small liver fluke Clonorchis sinensis (rev. by Doanh and Nawa, 2016), of which cercariae belong to the Parapleurophocercaria group. In this study, Parapleurophocercaria group cercariae from M. tuberculata snail were identified as the larvae of small intestinal flukes, H. pumilio and $P$. cheni. Since cercariae of $C$. sinensis and small intestinal flukes, $H$. pumilio and $P$. cheni, all belong to the Parapleurophocercaria group, it is possible that mis-identification might occur in the previous publications, in which the classification of cercariae from freshwater snails was solely based on the morphological characteristics (Doanh and Nawa, 2016).

In this study, ITS-2 sequence of Gymnocephalous group cercariae from $P$. striatulus snail was $97 \%$ similar to that of Sphaeridiotrema pseudoglobulus. This cercarial group found in Nam Dinh Province was classified as $S$. monorchis through the experimental infection in ducks (Besprozvannykh et al. 2013). The present results showed that the ITS2 sequence of $S$. pseudoglobulus from $P$. striatula snail was 97\% similar to that of S. monorchis.

The Echinostome groups from $B$. fuchsiana and $P$. striatulus snails were morphologically similar to each other, but the cercariae from $P$. striatulus was identified as E. japonicus with the similarity over $99 \%$. On the contrary, the cercariae from B. fuchsiana snails showed a lower level of ITS-2 sequence similarity (93\%) to E. japonicus. Thus, the Echinostoma groups from $B$. fuchsiana snails is possibly cercariae of another species, $E$. beleocephalus, which was reported in Vietnam (Le, 1995).

The Xiphidiocercaria group from $M$. tuberculata snail has the highest similarity (93\%) with Lecithodendrium spathulatum. The trematodes of the genus Lecithodendrium are typical trematodes of bats. In Vietnam, three species of the genus Lecithodendrium (L. daovantieni, L. rohdei, and Lecithodendrium sp.; Le, 1995) were reported in bats. However, molecular data of these species are not available in GenBank database for comparison.

\section{CONCLUSION}

Nine snail species were collected in $\mathrm{Ba} \mathrm{Vi}$ District, Ha Noi and 7 species were collected in Kim Son District, Ninh Binh Province. While three snail species, $R$. swinhoei, A. polyzonata, and $P$. canaliculata, were negative for cercariae, the other 6 snail species were infected with cercariae with low infection rates, ranging from $2.3 \%$ to $6.3 \%$. 
By morphology, 7 cercarial groups, Echinostome, Monostome Parapleurophocercaria, Xiphidiocercaria, Fucocercaria, Gymnocephalous, and Megalurous, were identified. The snail hosts $M$. tuberculata and $P$. striatulus were infected with 4 cercarial groups, snails $A$. viridis and $G$. convexiusculus were infected with 2 groups, snails B. fuchsiana and $T$. granifera were infected with one group.

By molecular identification, cercariae of nine trematode species, E. revolutum, $E$. japonicus, $N$. intestinalis, $P$. gralli, $H$. pumilio, $F$. gigantica, A. burti, C. prussica, and $P$. cheni, were identified. Among them, 3 species, $P$. cheni, A. burti and C. prussica, were recorded for the first time in Vietnam. In addition, Gymnocephalous cercaria from $P$. striatulus snail, which was classified as $S$. monorchis, showed $97 \%$ similarity of ITS-2 sequence with that of $S$. pseudoglobulus. Likewise, Echinostome group from snail $B$. fuchsiana was $93 \%$ similar to E. japonicus, and Xiphidiocercaria group from $M$. tuberculata snail showed $93 \%$ similarity of ITS-2 sequence with that of Lecithodendrium spathulatum.

Acknowledgements: This research is funded by the Vietnam National Foundation for Science and Technology Development (NAFOSTED) under a grant number 106NN.05-2016.17.

\section{REFERENCES}

Anucherngchai S., Tejangkura T., Chontananarth T., 2016. Epidemiological situation and molecular identification of cercarial stage in freshwater snails in Chao-Phraya Basin, Central Thailand. Asian Pacific Journal of Tropical Biomedicine, 6(6): 539-545.

Besprozvannykh V. V., Ngo H. D., Ha N. V., Hung N. M., Rozhkovan K. V., Ermolenko A. V., 2013. Descriptions of digenean parasites from three snail species, Bithynia fuchsiana (Morelet), Parafossarulus striatulus Benson and Melanoides tuberculata Müller, in North Vietnam. Helminthologia, 50(3): 190-204.
Bowles J., Hope M., Tiu W. U., Liu S. X., McManus D. P., 1993. Nuclear and mitochondrial genetic markers highly conserved between Chinese and Philippine Schistosoma japonicum. Acta Tropica, 55: 217-229.

Chau L. V., Lam K. T., De N. V., Son D. T., Mai D. T., Su T. T., 1996. Determination of the reservoir hosts and intermediate hosts of liver fluke. Proceedings of scientific research works of National Institute of Malariology Parasitology and Entomology 19911996. Medical Publishing House; 2: 6366. (in Vietnamese).

Chontananarth T., Wongsawad C., 2010. Haplorchis taichui infection of the freshwater snails and molecular identification. Trends Research in Science and Technology, 2(1), 7-12.

Chuboon S. and Wongsawad C., 2009. Molecular identification of larval trematode in intermediate hosts from Chiangmai, Thailand. Southeast Asian Journal of Tropical Medicine and Public Health, 40(6): 1216-1220.

Clausen J.H., Madsen H., Murrell K.D., Van P.T., Hung N.M., Viet K.N., Dalsgaard A., 2015. Relationship between snail population density and infection status of snails and fish with zoonotic trematodes in Vietnamese carp nurseries. PLoS neglected tropical diseases, 6(12): e1945.

Doanh P. N., Le N. T., 2005. Identification characteristics of trematoda cercaria groups and differentiation of ceracriae of Fasciola gigantica in Lymnaea snail in Vietnam. Tap chi Sinh hoc, 27(3): 31-36. (in Vietnamese).

Doanh P. N., Nawa Y., 2016. Clonorchis sinensis and Opisthorchis spp. in Vietnam: current status and prospects. Transactions of the Royal Society of Tropical Medicine and Hygiene, 110(1):13-20.

Dung B. T., Doanh P. N., Hien H. V., Huyen D. T. K., 2019. The distribution 
and situation of infection with trematode larvae in freshwater snails in some suburban districts of Hanoi. Proceedings of the 46th National Parasitology Conference. Publishing House of Agricultural Academy, p. 70-75. (in Vietnamese).

Dung B. T., Doanh P. N., The D. T., Loan H. T., Losson B. and Caron Y., 2013. Morphological and molecular characterization of Lymnaeid snails and their potential role in transmission of Fasciola spp. in Vietnam. Korean Journal of Parasitology, 51: 657-662.

Dung B. T., Madsen H., The D. T., 2010. Distribution of freshwater snails in familybased VAC ponds and associated waterbodies with special reference to intermediate hosts of fish-borne zoonotic trematodes in Nam Dinh Province, Vietnam. Acta Tropica, 116(1): 15-23.

Frandsen F., Christensen N. O., 1984. An introductory guide to the identification of cercariae from African freshwater snails with special reference to cercariae of trematode species of medical and veterinary importance. Acta Tropica, 41: 181-202.

Hung N. M., Dung D. T., Lan Anh N. T., Van P. T., Thanh B. N., Ha N. V., Hien H. V., Canh L. X., 2015. Current status of fishborne zoonotic trematode infections in Gia Vien district, Ninh Binh Province, Vietnam. Parasit Vectors, 8(1): 21.

Kim N. T., Vinh P. N., 1997. Investigation for the situation of liver fluke larvae in the snail intermediate host in the midlands of $\mathrm{Ha} \mathrm{Bac}$ and methods for prevention. Results of scientific research, Vietnam Institute of Agricultural Science and Technology, 5: 407-411. (in Vietnamese).

Le N. T., The D. T., Ngai D. D., Ngo D. H., 1995. Larvae of Trematoda and Cestoda in Lymnaea snails (Lymnaeidae family) in Ha Tay. Tap chi Sinh hoc, 17(1): 11-18. (in Vietnamese).

Le N. T., The D. T., 1993. Trematode larvae of snails belong to the family Pilidae and
Viviparidae in Ha Tay and Hoa Binh Provinces. Proceeding of Institute of Ecology and Biological Resources (19901992). Science and Technology Publishing House, Ha Noi, pp. 318-323. (in Vietnamese).

Le N. T., The D. T., Ngai D. D., 1990. Research on freshwater snails served as the intermediate host of trematodes infective to poultry. Proceeding of Institute of Ecology and Biological resources. Science and Technology Publishing House, Ha Noi, pp. 164-169. (in Vietnamese).

Le N. T., 1995. List of parasitic trematodes of Vietnamese birds and animals. Science and Technology Publishing House, p. 107-108. (in Vietnamese).

Le N. T., Doanh P. N., The D. T., 2000. The tapeworm larvae in the snail Parafossarulus striatulus (Bithyniidae) collected in Ba Vi and Ngoc Tao, Ha Tay Province. Tap chi Sinh hoc, 22: 15-21. (in Vietnamese).

Phuong N. T. X., Hien H. V., Huyen D. K., Dung B. T., 2019. Current status of trematode larval infection in intermediate host snail Melanoides tuberculata (Mollusca: Thiaridae) in $\mathrm{Ha}$ Vinh commune, Ha Trung district, Thanh Hoa Province. Proceedings of the 46th National Parasitology Conference. Publishing House of Agricultural Academy, pp. 38-44. (in Vietnamese).

Schell S.C., 1970. How to know the trematodes. W. C. Brown Co, America. pp. 21-33.

Thanh D. N., Bai T. T., Mien P. V., 1980. Identification of freshwater invertebrates of Northern Vietnam. Science and Technology Publishing House, Ha Noi, pp. 230-250. (in Vietnamese).

The P. H., 1993. Determination of intermediate hosts of small liver fluke Clonorchis sinensis in a region with a habit of eating raw fish. Practical Health Magazine, 2: 23-25. (in Vietnamese). 